\title{
Applying Livelihood Vulnerability Index in Studying Livelihood: A Case Study in An Giang Province, in the Mekong Delta, Vietnam
}

\author{
Phu PX*1 and Tran NTB ${ }^{2}$ \\ ${ }^{1}$ Department of Rural Development and Natural Resources Management, Faculty of Agriculture and Natural Resources, \\ An Giang University, Vietnam \\ ${ }^{2}$ Department of Animal Husbandry and Veterinary, Faculty of Agriculture and Natural Resources, An Giang University, Vietnam
}

*Corresponding author: Phu PX, Long Xuyen City, Faculty of Agriculture and Natural Resources,An Giang University, Long Xuyen City, An Giang, Vietnam

\begin{tabular}{l} 
ARTICLE INFO \\
\hline Received: 幽 March 22, 2019 \\
Published: 幽 April 01, 2019 \\
Citation: Phu PX, Tran NTB. Applying \\
Livelihood Vulnerability Index in Study- \\
ing Livelihood: A Case Study in An Giang \\
Province, in the Mekong Delta, Vietnam. \\
Biomed J Sci \& Tech Res 16(4)-2019. \\
BJSTR. MS.ID.002878.
\end{tabular}

\begin{abstract}
Imitating Livelihood Vulnerability Index (LVI) raised by Hahna et al. [1] a study of livelihood vulnerability of different Zone (upper zone, middle zone, lower zone) in low flooding condition. Research results showed that (LVI) of different Zone (upper zone, middle zone, lower zone) are decreasingly dependent on major components of social networks, knowledge and skills, natural resources, finance and incomes, livelihood strategies, natural disaster and climate variability. In which, (LVI: 0,397) of Phu Huu commune in An Phu district which locates in the upper zone is higher than LVI of two communes located in the lower part of the river. These communes are Vinh a commune (LVI: 0,299), Chau Thanh district (middle zone) and Vinh Phuoc commune (LVI: 0,357), Tri Ton district (lower zone) and adaptive capacity of Phu Huu commune $(0,415)$ is also higher than Vinh An $(0,304)$ and Vinh Phuoc $(0,355)$. It reflects the direct proportion between LVI and adaptive capacity. The research recommends some solutions to reduce the vulnerability on livelihoods due to floods in the context of climate change.
\end{abstract}

\section{Introduction}

A Giang is a province in the Mekong downstream area influenced by annual flood. Flood brings large amounts of silt to build up and improve soil fertility; field sanitation, washing alum Dao Cong Tien [2], creating jobs and income for people in the flooding season such as fishing, vegetables and travel services. Besides, the floods also cause damage to agriculture, livelihoods of people in floodplains; specifically, the flood lasts from October to November by Mekong water combined with heavy rain water causing flood in most of the districts in the province and urban areas during big floods. Low areas covered in water from $1.5 \mathrm{~m}$ to $4.5 \mathrm{~m}$ causing huge damage to property and people's lives (Irrigation Department of A Giang [3]). However, only few studies assess the vulnerability of flood due to people's livelihoods changes in flooding areas (at the upstream, middle and downstream) in a comprehensive way considering all aspects (human, natural, financial, physical and social ones) under the increasing effect of climate change and flood changes for appropriate solutions to reduce the vulnerability of people's livelihoods in flooding areas. Therefore, the research on "Applying livelihood vulnerability index in studying livelihood: A case study in A Giang province, in the Mekong Delta, Vietnam" is considered as a basis reference which proposes necessary solutions to improve people's livelihood effectively and sustainably.

\section{Research Objectives}

a) Assessing vulnerability and adaptability to the flood changes in different conditions on farmer livelihoods.

b) Proposing strategic solutions to reduce vulnerability from flooding in the context of climate change on farmer livelihoods.

\section{Research Methods}

\section{Constructing Livelihood Vulnerability Index(LVI)}

This study adopts the sustainable Livelihood Framework (Birkmann [4]) to guide the assessment of livelihood vulnerability 
to floods. The Sustainable Livelihood Framework (SLF) where vulnerability context is major determinant of sustainability of livelihood assets as it directly influences livelihood strategies, institutional process and livelihood outcomes of community (Chambers and Conway [5]; DFID [6]). The effects of floods and climate variability have been considered under the vulnerability context of SLF. The level of vulnerability of community determines the impacts of floods and climatic conditions on people's livelihood assets, strategies and outcomes. This study aimed at caculating level of vulnerability to the impacts of those extreme floods and climate variability in three diffrent floods communes such as upstream commune (Phu Huu), middlestream (Vinh An) and downstream (Vinh Phuoc) of An Giang province, Mekong Delta of Vietnam by applying a LVI that development by Hahn et al. [1]. The components that are the indicators of vulnerability of community to flood impacts are presented in Table 1. These components are classified under 5 different livelihood assets in SLF: human, physical, social, natural, financial. The sub-components have been developed as indicators under a single component which are shown in Table 1.

Table 1: Capitals, major component and sub-component comprising the livelihood vulnerability index.

\begin{tabular}{|c|c|c|}
\hline Capitals & Major Component & Sub-Component (Indicator) \\
\hline \multirow[t]{11}{*}{ Human } & Health & Percent of HHs with family member with illness \\
\hline & & Percent of HHs with family member get illness due to flood \\
\hline & Knowledge \& skills & Percent of HHs head unlettered \\
\hline & & Percent of HHs head just passed primary school \\
\hline & & Percent of HHs head that no receive any training to cope with flood \\
\hline & Livelihood strategy & Average agriculture livelihood diversity \\
\hline & & Percent of HHs dependent on agriculture as major source of income \\
\hline & & Percent of HHs reported no non-farm activities as affected by flood \\
\hline & & Percent of HHs with no jobs (during flood season) \\
\hline & & Percent of HHs exploring natural resources (during flood season) \\
\hline & & Percent of HHs do fishing (during flood season) \\
\hline \multirow[t]{10}{*}{ Natural } & Land & Percent of HHs with landless \\
\hline & & Percent of HHs with small land (0.1- 0.5 ha) \\
\hline & Natural resources & Percent of HHs that not cultivate the 3rd crop \\
\hline & & Percent of HHs that depend on (exploit) natural resources \\
\hline & & Percent of HHs that depend on (do) fishing during flood \\
\hline & $\begin{array}{l}\text { Natural disasters and } \\
\text { climate variability }\end{array}$ & Average number of most severe flood in the past 15 years \\
\hline & & Average of death/injury as result of most severe flood in the past 15 years \\
\hline & & Percent of HHs did not receive a warning about flood \\
\hline & & Mean standard deviation of monthly average of average water level in Tan Chau from 2000 to 2015 \\
\hline & & Mean standard deviation of precipitation by month (average 15 years) \\
\hline \multirow[t]{6}{*}{ Social } & Socio-demographic & Dependency ratio \\
\hline & & Percent of female head HHs \\
\hline & & Average family member in a HHs \\
\hline & & Percent of poor HHs \\
\hline & Social network & Percent of HHs receive helps due to flood \\
\hline & & Percent of HHs that have not been membering of any organizations \\
\hline \multirow{3}{*}{ Physical } & & Percent of HHs that with housing affected by flood (partially to totally submerged) \\
\hline & Housing \& prod. means & Percent of HHs that with non-solid house \\
\hline & & Percent of HHs that report no access to production means \\
\hline \multirow[t]{3}{*}{ Financial } & & Percent of HHs borrow money \\
\hline & & Percent of HHs with net HHs income lower 1000 USD \\
\hline & & Percent of HHs with non - income within flood season \\
\hline
\end{tabular}




\section{Calculating the Livelihood Vulnerability (LVI)}

The information was collected by interviewing 180 households in upstream commune (Phu Huu), middlestream (Vinh An) and downstream (Vinh Phuoc) and Livelihood Vulnerability Index (LVI). According to Hahn et al (2009), LVI is applied to assess the impact of flood damage to the livelihoods of people in flooding areas. LVI index has two approaches: (1) LVI is represented as a compound index including seven major factors (household characteristics, livelihood strategies, social networking, health, food, water, natural disasters and climate change), each main factors including a few indicators or additional factors; (2) seven key elements combine into the three "contributing agents "including exposure, sensitivity / and adaptability (as defined by the Intergovernmental Panel on Climate Change IPCC - Intergovernmental Panel on Climate Change). Each additional factor measured in different system and should be standardized as an index according to the following equation:

$$
\text { index }_{s_{d}}=\frac{S_{d}-S_{\min }}{S_{\max }-S_{\min }} \quad \begin{aligned}
& S_{d} \text { is the original value of the additional factors for the local } \mathbf{d}, \\
& S_{\min } \text { and } \mathbf{S}_{\max } \text { minimum and maximum value }
\end{aligned}
$$

Once standardized, additional factors are averaged to calculate the value of each element by the following equation: Once values of the key elements are identified, local livelihood vulnerability index (communal level) is calculated according to the equation:

$$
M_{d}=\frac{\sum_{i=1}^{n} \text { index }_{s_{d} i}}{n} \quad \begin{aligned}
& M_{d}: \text { one of the main factors for local } \\
& \text { index }_{s d} \text { i additional factors are recorded as } \mathbf{i}
\end{aligned}
$$

$L V I_{d}=\frac{\sum_{i=1}^{n} W_{M_{i}} M_{d i}}{\sum_{i=1}^{n} W_{M_{i}}} \quad W_{M i}$ is determined by the number of additional factors creating key elements.
LVI is about $[0,1], \mathrm{LVI}$ the closer to 1 , the higher vulnerable rate.

LVI-IPCC: LVI of p commune is calculated by using IPCC.

$$
\left.L V I-I P C C p=\left(e_{p}-a_{p}\right) * S_{p} \quad \text { (value ranges from }-1 \text { to } 1\right)
$$

IPCC: CFP - is defined as the main components of the level of exposure, sensitivity, adaptive capacity for each p commune.

$$
C F_{P}=\left(\sum_{i=1} W M i M_{p i} / \sum_{i=1} W M i\right) \quad \begin{aligned}
& M p_{i}: \text { main factors of } p \text { commune, index recorded as } \mathbf{i} \\
& W_{m}: \text { the degree of each component }
\end{aligned}
$$

Key components of the level of influence (e) include climate change; capacity of adaptation (a) the household characteristics, livelihood strategies and social networks; sensitivity level (s), including the main components of knowledge, skills and health care, natural resources such as land and finance.

\section{Results and Discussion}

\section{Assessment on Vulnerability to Flood Changes on the Livelihoods of Farmers in an Giang Province}

Through the analysis of sources and livelihood vulnerability index (LVI) of 10 key components, 30 subcomponents and 5 financial sources (Table 2 and Figure 1) show that the upstream is the most vulnerable area, specifically, livelihood vulnerability index (Average of $\mathrm{H}, \mathrm{N}, \mathrm{S}, \mathrm{P}, \mathrm{F}$ ) in Phu Huu commune is the highest at 0,397; Vinh Phuoc commune at 0,357; and the lowest is Vinh an commune at 0,299 . Within 5 financial sources, human, financial and social sources have high vulnerability index in all three regions; physical sources have the lowest vulnerability index.

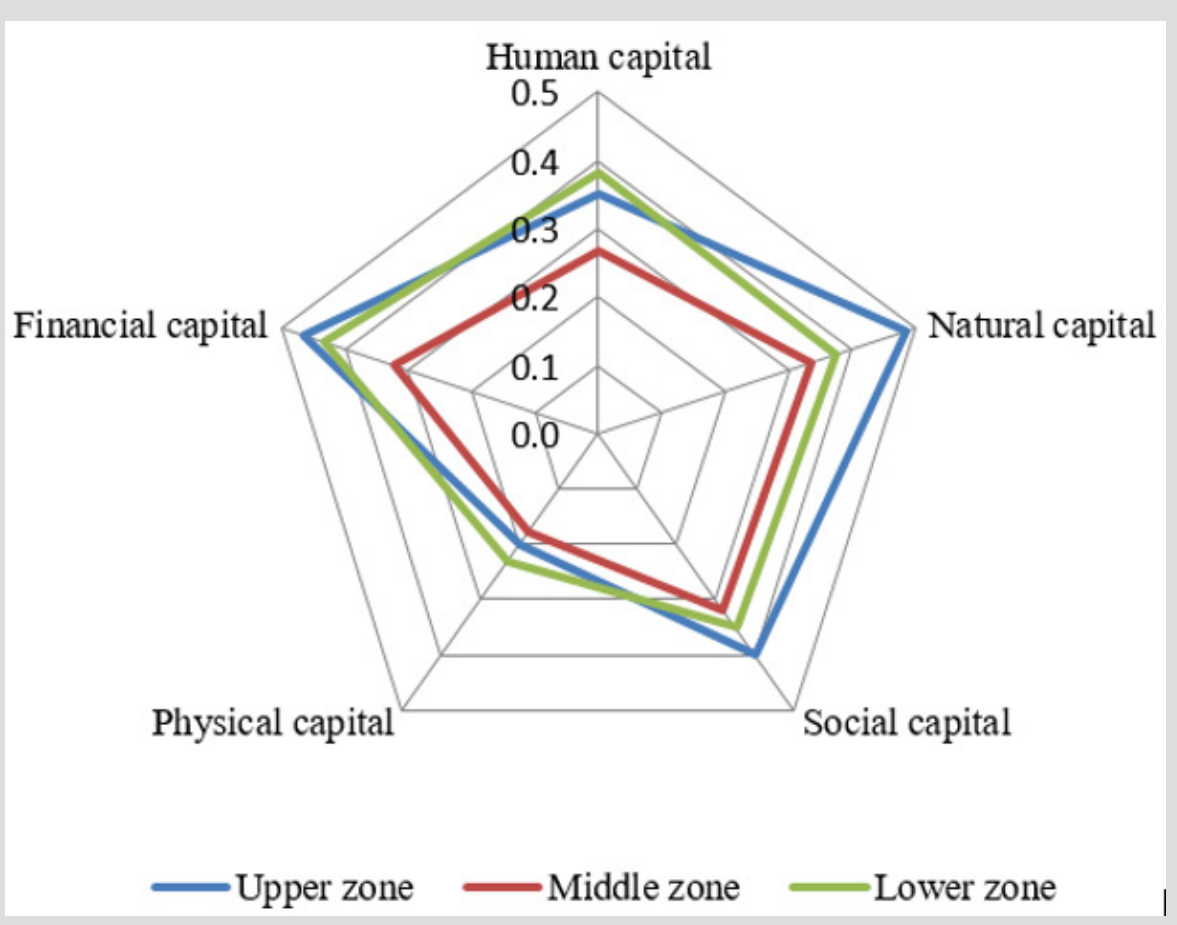

Figure 1: Vulnerability diagram of five capitals of SLF of Phu Huu, Vinh An, Vinh Phuoc communes, 2016. 
Table 2: Vulnerability triangle of the contributing factors of the LVI-IPCC for Phu Huu, Vinh An and Vinh Phu communes.

\begin{tabular}{|c|c|c|c|c|c|c|c|}
\hline Major component & Phu Huu & Vinh An & Vinh Phuoc & Contributing factors & Phu Huu & Vinh An & Vinh Phuoc \\
\hline Socio-demographic & 0.245 & 0.164 & 0.239 & Adaptive capacity & 0.415 & 0.304 & 0.355 \\
\hline Livelihood strategy & 0.400 & 0.277 & 0.322 & & & \\
\hline Social networks & 0.800 & 0.667 & 0.683 & & & \\
\hline Health & 0.100 & 0.017 & 0.050 & Sensitivity & 0.337 & 0.269 & 0.307 \\
\hline Knowledge \& skills & 0.584 & 0.517 & 0.733 & & & \\
\hline Land & 0.367 & 0.384 & 0.350 & & & \\
\hline Natural resources & 0.466 & 0.342 & 0.370 & & & \\
\hline Financial & 0.465 & 0.322 & 0.434 & & 0.286 & 0.189 & 0.217 \\
\hline $\begin{array}{c}\text { Natural disasters and climate } \\
\text { variability }\end{array}$ & 0.286 & 0.189 & 0.217 & Exposure & -0.043 & -0.031 & -0.042 \\
\hline
\end{tabular}

Vulnerability Index LVI-IPCC of 3 Research Areas Including Upstream, Midstream and Downstream

Results calculated in accordance to LVI-IPCC (level of influence, adaptability and sensitivity) based on the sub-components of household characteristics, livelihood strategies and social networks in three communes in Phu Huu Vinh An, Vinh Phuoc (Table 2) indicate that interviewed households in Phu Huu (upstream commune) with greater level of influence, sensitivity and adaptability than households in Vinh An and Vinh Phuoc; Vinh An commune (midstream) has lowest level of influence, sensitivity and adaptive capacity.

\section{Conclusion and Recommendation}

Floods are a natural phenomenon and occur annually. Complicated and irregular floods caused difficulties to people's livelihood in An Giang province. Research findings on livelihood vulnerability index (LVI) including 10 key components, 30 subcomponents and 5 livelihood sources showed that people in $\mathrm{Phu}$ Huu commnue have the highest vulnerability. (With livelihood vulnerability index at 0,397), followed by Vinh Phuoc Commune $(0,357)$, and Vinh An is the lowest $(0,299)$. Besides, the results also indicated that one area that is more vulnerable will have higher adaptability. For instance, adaptability of Phu Huu is higher than Vinh An and Vinh Phuoc Commune $(0,415$ compared to 0,304 and 0,355 ). To reduce vulnerability, early warning systems should

ISSN: 2574-1241

DOI: 10.26717/BJSTR.2019.16.002878

Phu PX. Biomed J Sci \& Tech Res

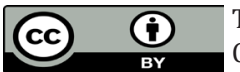

This work is licensed under Creative Commons Attribution 4.0 License

Submission Link: https://biomedres.us/submit-manuscript.php be developed to decrease flood damage to people's livelihoods. Also, to prepare for the flood season, it is necessary to strengthen propaganda and dissemination of knowledge. Local authorities should organize training courses on unusual flood adaptation. Moreover, the government should have insurance policies for people in flooded areas to ensure their livelihood and reduce the vulnerability of climate change conditions.

\section{References}

1. Micah B Hahna, Anne M Riederer, Stanley O Foster (2009) The Livelihood Vulnerability Index: A pragmatic approach to assessing risks from climate variability and change - A case study in Mozambique. Global Environmental Change 19(1): 74-88.

2. Dao Cong Tien (2001) Flooding area in Mekong Delta. The current situation and solution. Ho Chi Minh publishing house.

3. (2016) Irrigation Departments of a Giang province. Summary report of yield natural resource from 2000-2015.

4. Birkmann J (2006) Measuring vulnerability to promote disasterresilient societies: Conceptual frameworks and definitions, in Joern Brikmann (Ed.).). Measuring vulnerability to natural hazards: Towards disater resilient societies. United Nations Unversity Press, p. 9-54.

5. Chamber R, Conway G (1992) Sustainable rural livelihood: practical concept for the $21^{\text {st }}$ century. IDS Discussion paper 296. Institute of Development Studies, Brighton, UK.

6. DFID (2000) Sustainable livelihood guidance sheets. DFID 94 Victoria Street, London, SWE5JL, UK.

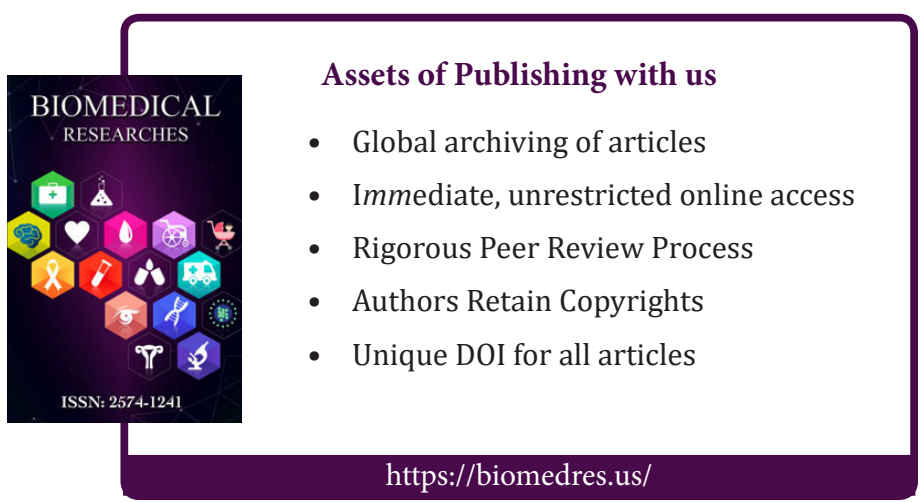

